WŁADYSŁAW SowA

Studia Theologica Varsaviensia

\title{
Redemption by a Renewed Creation in Christ According to the "Gaudium Et Spes"*
}

\section{Introduction}

"The Second Vatican Council, after an in-depth reflection on the mystery of the Church, addresses without hesitation its words not only to the sons of the Church and all those who call upon the Name of Christ, but to all people... He has before his eyes, therefore, the world of mankind, that is to say the whole human family, the world of all that it lives in, the world of the human race," marked by monuments to its efforts, defeats and victories (GS 2). Another text states that "in our day, mankind, moved by admiration for its inventions and its power, often discusses disturbing questions concerning today's evolution of the world, man's place and task in the universe, the sense of his individual and collective effort, and finally the ultimate goal and things and people" (GS 3). The Council therefore establishes with the human family "a dialogue on these various problems, speaking, bringing light to the Gospel and providing the human race with the salvific power which the Church herself, under the guidance of the Holy Spirit, receives from its Founder" (ibid.). In another place, the Constitution states that "in the light of Christ, the image of the invisible, firstborn God, of all creation, the Council wishes to speak to all in order to clarify the mystery of man and to cooperate in finding a solution to the main problems of our time" (GS 10).

From the Council texts cited only selectively, one can see that Gaudium et Spes is the "word" addressed by the Council to the care of the whole world, and in it to all people without exception, to the concrete man, taken as a whole in his unity and totality, with body and soul, with heart and conscience, mind and will. The issue of man became the axis of the whole argument (cf. GS 3). 
The pastoral Constitution, therefore, deals mainly with issues concerning man and his urgent matters. For this anthropological problem, however, he seeks a theological basis, which he finds in the Christological interpretation of man and the world.

In this context, the doctrine of Redemption, which is the central reality of the Christian religion and concerns man and the world in which he lives, is shown. Therefore, the redemption accomplished by Christ is one of the main themes that runs through the entire Constitutions. Gaudium et Spes, although it is a pastoral constitution, contains in its composition, at the end of each of the four chapters of the first part, points of dogmatic type. Thus, in Chapter I, number 22 is entitled: "Christ the new man." In Chapter II, we find the number 32, which has the title: "The Incarnate Word and Human Solidarity." There are two numbers in Chapter III: number 38: "Human activity brought to perfection in the paschal mystery" and number 39, entitled: "A new earth and a new sky." In Chapter IV, we find number 45: "Christ the Alpha and Omega." This is why this Constitution is perhaps the most appropriate source to provide a comprehensive response to the complex problem of redemption for man, living in the Church and in the modern world.

It should also be added that the Council's doctrine of redemption is read not only in the conciliar document finally drafted, approved by the Council Fathers and approved by Pope Paul VI on 17 XII1965, but also first on the basis of the earlier statements of bishops and experts, expressed as demands to the future Council, which signal current theological problems that are awaiting clarification. They are contained in 27 Latin volumes: Acta et Documenta Concilio Oecumenico Vaticano secundo apparando ${ }^{1}$. We then base ourselves on the four previous editions of the text Gaudium et Spes ${ }^{23}$ as well as the statements of the Council Fathers, which take place after each editorial office. They are expressed orally in the Council Hall, as so-called Pairara orationes or attached in writing as Animad iversiones scriptaie adhibendae, and contained in 25 volumes of Acta Synodalia Sacrosancti Concilii Oecumenci Vaticani Secundi. It is necessary to rely on this vast source material in order to be able to trace the development of the various problems of redemption, starting with their signalling in the postulates,

1 Acta et Documenta Concilio Oecumenico Vaticano II Apparando, Vaticanis 1960-1973. (Abbreviation used for further quote: $\mathrm{AD}$, series, volume, pars.).

2 Four schematics: I Scheme of 3 VII1964, II Scheme of 28 V1965, III Scheme of 13 XI 1965 and IV Scheme of 2 XII 1965.

3 Acta Synodalia Sacrosancti Concilii Oecumenici Vaticani secundi, Vaticanis 1970-1978. (Abbreviation used for further quote: AS, volumen, pars.). 
through attempts to resolve them throughout the process of drafting the final version of the document, to find their resonance in the numerous commentaries on Gaudium et Spes, of great scientific value ${ }^{4}$.

[This article constitutes, in a very small way and in addition very synthetically presented part of a larger work ${ }^{5}$, and is entitled: "Redemption by a renewed creation in Christ."]

\section{Salvific Incarnation}

In the postulants expressed before the Council concerning the problems of redemption we observe a polemical tendency in relation to the various theological trends of today that do not accept the reality of redemption ${ }^{6}$. They also pay attention to the reduction of redemption value today and its minimal impact on the way we think and the attitudes of modern delusions toward Earthly realities. ${ }^{7}$

4 We will limit ourselves to indicating only a dozen or so of the most basic comments: $L a$ Costituzione Pastorale sulla Chiesa nel mondo contemporáneo "Gaudium et Spes." Testo latino e italiano con commenta e note. Rome 1967; La Chiesa incontro al mondo. Per una letture della Costituzione Pastorale su "La Chiesa nel mondo contemporáneo". Testo della Costituzione presentato e commentato da Dionigi Tettamanzi. Milan 1967; La Chiesa nel mondo contemporáneo. Commento alla Costituzione Gaudium et Spes, Brescia 1966; La Chiesa nel mondo contemporáneo. Costituzione Pastorale del Concilio Vaticano II, Torino 1967; La Chiesa nel mondo di oggi. Studi e commenti intorno alla Costituzione Pastorale Gaudium et Spes, Firenze 1966; Commentary on the documents of Vatican II, ed. H. Vorgrimler, volume five, Pastoral Constitution on the Church in the Modern World. History of the Constitution by Ch. Moeller, New York 1969; Commento alla Costituzione Pastorale su la Chiesa nel mondo contemporáneo "Gaudium et Spes", Milan 1967; Constitution Pastorale "Gaudium et Spes". L'Eglise dans le monde de ce temps, Paris, 1966; La Costituzione Pastorale sulla Chiesa nel mondo contemporáneo. Introduzione storico-dottrinale, Leuraam 1968; L'Eglise dans le monde de ce temps. Concile Vatican II, Gaudium et Spes, Paris 1968; L Eglise dans le monde de ce temps. Constitution Pastorale "Gaudium et Spes", vol. 3, Paris 196; Gaudium et Spes. L'Eglise dans le monde de ce temps. Introduction Générale, Paris 1967; Das Zweite Vatikanische Konzil. Konstitutionen, Dekrete und Erklärungen. Lateinisch und Deutsch. Kommentare I-II-III, in: Lexikon für Theologie und Kirche, Freiburg-Basel-Wien, 1966-1968.

5 All this research is included in the doctoral dissertation by the author, written under the direction of Prof. J. Galot at the Faculty of Theology of the Pontifical Gregorian University in Rome. Cf. A.W. Sowa, II mistero della Redenzione nella Gaudium et Spes, Rome 1983.

6 Cf. F. Cleretde Langavant, in: AD, s. I, vol. II, p. V, 243; Facultas Theologica Carmelitarum Discalceatorum, in: AD, p. I, vol. IV, p. I 2, 321. 332. 336; B. Evangelisti, in: AD, s. I, vol. II, p. IV, 173; A. Lombardi, in: AD, p. I, vol. II, p. VII, 311.

7 Cf. M. Blanchel, in: AD, p. I, vol. Il, p. III, 52; A. Fares, in: AD, p. I, vol. II; p. III, 178; G.P. Bartholome, in: AD, p. I, vol. II, p. VI, 430. 
The lack of true soteriology on the part of theologians, not excluding Catholic ones $^{8}$, was also pointed out, as well as a proposed return to the teachings of Saint Thomas Aquinas ${ }^{9}$. As for the issues related to the Incarnation itself, various tendencies could be observed: the first proposed to take the Incarnation and redemption separately ${ }^{10}$. Another suggestion was to treat them together as one reality ${ }^{11}$ and another as a salvific Incarnation ${ }^{1213}$ or about redemption as the goal of the Incarnation.

The Council tries to meet these demands and slowly, in stages, specifies its teaching. It first treats the Incarnation as the source of human dignity. In Schema I of July 30, 1964, it attributes this dignity to the individual and to the whole created world ${ }^{14}$, but as a result of the intervention of the Fathers ${ }^{15}$, Scheme II of May 28, 1965, extends the scope of this dignity from the Incarnation to the human community and human activity, as well as to the entire history of the world ${ }^{16}$. The interventions of the Fathers after the Second Schema bring two novelties. The first is expressed in the affirmation that Christ, through the Incarnation, creates a new man who has a duty to perfect human nature, and this is the collaboration with the work of the Incarnation ${ }^{17}$. The second novelty, coming from Eastern theologians, is expressed in the suggestion to treat the Incarnation as a basis for working out the cosmic theology ${ }^{18}$.

The first Schema did not speak clearly about the Incarnation in the perspective of redemption. Although the text says that Christ is the true man who came to free himself from the bondage of $\sin ^{19}$, there is no deeper theological precision in the text. Also the interventions of the Fathers after Scheme I emphasized that the motive of the Incarnation is the liberation of man from the

Cf. N. Jubany Arnau, in: AD, p. I, vol. II, p. II, 458.

9 Cf. S. Congregatio S. Officia, in: AD, p. I, vol. III, 1-17.

10 Cf. F. Longinotti, in: AD, p. I, vol. II, p. III, 588.

11 Cf. J. J. Weber, in: AD, p. I, vol. Il, p. I, 413; D. Feeney, in: AD, p. I, vol. II, p. VI, 409.

12 Cf. A.G. Mayer, in: AD, p. I, vol. II, p. VI, 292; F. Guerry, in: AD, p. I, vol. II, p. I, 254.

13 Cf. J.E. Mac Manus, in: AD, p. I, vol. II, p. VI, 645.

14 Schema I, in: AS, vol. III, p. I, 119.

15 Cf. A. Fernandez Alonzo, in: AS, vol. III, p. V, 353; P. Barra china y Estevan, in: AS, vol. III, p. V, 723; M. Mariere, in: AS, vol. III, p. V, 480; M. Pourchet, in: AS, vol. III, p. V, 594-603; A. Fernandez Alonzo, in: AS, vol. III, p. V, 354; R. Gonzales Moralejo, in: AS, vol. III, p. V, 388.

16 Cf. Schema II, in: AS, vol. IV, p. I, 448.458.485.

17 Cf. Plures Patres Concïliares Galliae, in: AS, vol. IV, p. II, 915. 918. 922.

18 Cf. P.P. Meouchi, in: AS, val. IV, p. II, 423

19 Cf. Schema I, in: AS, vol. III, p. V, 116.118.121. 
slavery of the devil, sin and death. We also find there a clearer suggestion that proposes to look at the Incarnation as conditio sine qua non redemption ${ }^{20}$. The Second Schema takes up these postulates and speaks more clearly of the Word of the Father which, through its incarnation, has accepted the whole created reality, and all that exists needs, invokes, each in its own way, the Redeemer ${ }^{21}$. In subsequent interventions, the Fathers demand that we do not 'see in the Incarnation only the source of the beauty of human nature. They indicate that the Incarnation is primarily for redemption. The saving nature of the Incarnation cannot be forgotten ${ }^{22}$. There were also tendencies to treat redemption not as the goal of the Incarnation, but as a means of sanctification ${ }^{23}$. However, the last editions of the text - Scheme III of 13.11 .65 and Scheme IV of 2.1.2.65. reject such an opinion and confirm that Christ came to save the world, that is, to accomplish the work of redemption ${ }^{24}$. It is now necessary to look at how the final text of our document illuminates the mystery of the Incarnation in order to obtain a complete picture of it.

The mystery of redemption is presented in the Gaudium et Spes primarily as the work of Jesus Christ. This work was initiated by Jesus in His Mystery of the Incarnation. Christ became man and through his Incarnation gave great dignity to every man, to all human nature. Man has become a great mystery. But man as a person lives in connection with other people, lives in society. Christ, entering into human society through His Incarnation, emphasized its value, gave it dignity, and sanctified all social relationships. Also, all human activity derives its great value from the mystery of the Incarnation.

Christ, entering into history, wants to give great dignity to all human activity. Through the Incarnation, Christ took up a part of the material world, that is, the whole human body, and in it took up the whole universe, that is, the whole effect of the work of creation, and thus also the matter and all goods, temporal and earthly, thus giving them great dignity.

20 Cf. J. Frings, in: AS, vol. III, p. V, 562; A. Del Rosario, in: AS, vol. III, p. V, 413; R. Gonzales Moralejo, in: AS, vol. III, p. V, 389; C. De Proveneheres, in: AS, vol. III, p. V, 632; H. Routhier, in: AS, vol. III, p. VII, 350; P. Barrachina y Estevan, in: AS, vol. III, p. V, 723; R. J. De Roo, in: AS,vol. III, p. V, 530.

${ }^{21}$ Schema II, in: AS, vol. IV, p. I, 436.465.469.

${ }^{22}{ }^{22}$ Cf. G. De Proença Sigaud, in: AS, vol. IV, p. II, 50; J. Marafini, in: AS, vol. IV, p. II, 412; S. Lourdusamy D lirais and we, in: AS, vol. IV, p. II, 382; S. Quadri, in: AS, vol. IV, p. II, 818; P. Parente, in: AS, vol. IV, p. II, 803.

23 Cf. A. Elchinger, in: AS, vol. IV, p. II, 1035.

24 Cf. Schema III, in: AS, vol. IV, p. VI, 442. 
Thus, the whole mystery of man, in its full context and meaning, that is, in its personal, social and historical dimension, has received this dignity precisely through the mystery of the Incarnation, which is the source and summit of human dignity.

However, Christ did not come into the world only to give the highest dignity to man and the whole of created reality. Christ came to save it, to redeem it. Redemption is the main goal of the Incarnation. Christ was foreseen by God as the causer of the work of redemption from the moment of creation. From the very beginning we can speak of the absolute primacy of Christ the Redeemer. We have received this most wonderful, most selfless gift, the gift of the Redeemer, which should renew, divinise and unite the whole created reality, in the salvific Incarnation.

\section{Redemptive Paschal Mystery}

Christ as the Redeemer fulfilled his work in the Paschal Mystery. The first stage of this mystery is the true death of Christ. It is a substitution, and thus the substitution of Christ for sinful men, but not a penal substitute, but a voluntary substitution of someone innocent for the guilty. Christ was established as the representative of all mankind, Christ's death is death for all men, and therefore has universal value.

The second phase of Christ's paschal mystery, through which he accomplished redemption, is the resurrection. The salvific value of the resurrection is connected with the very real fact of the resurrection, which reveals to us first of all the victory of Christ over death, the transition from death to life. We are talking here about the so-called "transitional" nature of the resurrection. Through the resurrection, Christ is in a glorious state in which he has a new life, a life of spirit, forever. This in turn constitutes the lasting character of the resurrection on which its salvific value is based. The soteriological value of the resurrection extends to the man taken in his bodily and spiritual entirety, that is to say, all of human nature. The human body should also participate in redemption and be subject to poverty. Consequently, the entire material world, which is somehow enclosed, contained in the human body, is also destined for the same purpose, and is drawn to this very destiny, i.e. to the resurrection. Therefore, the resurrected body of Christ is the resurrection of the whole created visible world. So the resurrection has its cosmic aspect. It is not only Christ's victory, but in Christ it is a complete triumph of the whole of created reality. This is also the saving effectiveness of the resurrection. 
The resurrection is closely connected with the Ascension. This refers to the state of Christ after the resurrection and, as such, also has its salvific value. Ascension as the planting of Christ at the right hand of God is not only the enthronement of the Messiah in his kingdom or the fulfilment of prophecies. It is an event that extends, expands and spreads due to the ultimate possession of messianic power. This power is the royal power to rule over all creation. It is also the priesthood authority of Christ who ascended to heaven after making the sacrifice of his life. He did so as High Priest at the time of his death on the cross. This priestly authority is the power of sanctification that permeates all human existence. Christ as the head of his body also has the power to give life to the Mystical Body through Ascension. Therefore, the reality of the Ascension can create a picture, that is, humanity and the universe filled with eternal life.

The Ascension leads to the realization of the last event of the salvific drama, i.e. the exaltation of the Holy Spirit in Green Week. Christ the Redeemer sent Holy Spirit into the hearts of the people. Thanks to him, the mystery of redemption will always survive as alive and effective until the final coming of Christ. The Holy Spirit inspires, purifies and strengthens people in their contact with God, securing their intimate belonging to Him. Through the sending of the Holy Spirit, the covenant between God and men is fulfilled. The realization of this covenant is very closely connected with the Church, which has been given the gift of the Holy Spirit. The Church is always born in the dynamism of expansion. The dynamism of the Church in fulfilling her universal mission comes from the Holy Spirit. It is He who continues in the Church the work of redemption accomplished by Christ. Through the many gifts, they will stimulate Christians to bear witness, which is crucial, even indispensable, in the process of the Church's growth, that is, in the fulfilment of its mission. This continuation of the Church's redemptive work through the power of the Holy Spirit will be carried out in a living and effective manner until the final coming of Christ in glory.

The action of the Holy Spirit - always rapping on the future already extends to the human individual in the first place, liberating him or her internally. This liberation is spiritual, and it is a liberation based on love. The sending of the Holy Spirit, closely connected with the resurrection, also offers us a new life. The spill of the Holy Spirit is the spill of life. This new life begins within the redeemed man who has become a new creation in the Holy Spirit and has been internally redone. The image of a human being has also been made a new reality and has become a new creation. Therefore, the sending of the Holy Spirit as the last event in the drama of redemption is the cause, the source of the renewal 
of all creation. In conclusion, the soteriological value of the exile of the Holy Spirit at Pentecost lies in the fulfilment of the covenant with the Father in the fact that it is the omnipotence of the beginning of the mission and development of the Church, in the inner liberation accomplished in the Holy Spirit, in the constant exile of the Holy Spirit until the second coming of Christ and in the fact that the exile of the Holy Spirit is the cause and source of new life and the renewal of all creation.

Thus, the redemption accomplished has its multiple value. First, as the tearing apart of Satan's bondage and sin. Redemption not only took away sin, but also took away sin and its perpetrator, Satan. On the positive side, redemption is an achievement of the true freedom offered to us by Christ. A man freed from this bondage can become more fully involved in his work, always giving it a salvific value.

Another value of redemption lies in making a new covenant with the Father. This covenant was renewed by Christ as an innocent lamb. He is the sacrifice for sins. His blood resembles perfectly the blood of the covenant made with God in Sinai when God took the people of Israel for His people. In the mystery of redemption, all men became newly owned by God, the acquired blood of Christ shed on the cross.

Reconciliation with God and men is the third value of redemption, as indicated in our Constitution. This reconciliation was accomplished through Christ's death on the cross. The whole and paschal mystery freed man from the bondage of sin, which destroyed the unity of people with God and among themselves. Consequently, redemption has brought about a new unity between people and God and between themselves. It became a reconciliation.

The fourth value of redemption lies in the service of our lives. Christ merited our lives through His death and resurrection. In the death of Christ, man was freed from death. Death has been defeated. In the resurrection man receives life because the resurrection is the mystery of life.

The revelation of the mystery of love, also mentioned explicitly in Gaudium et Spes, can be mentioned as the fifth value of Redemption. This love is so great that it eliminates any distance between the God of holiness and the people of sin. Therefore, God gave His Son to accomplish redemption through His entire paschal mystery. The entire salvific "work" of salvation, directed towards the created reality, is inspired and carried out only by the love of the Father and the love of the Son. This love is manifested in the mystery of redemption by Christ, who offered his life for others. It also affects people who, by participating in God's love and receiving its saving fruits, should keep the greatest commandment of love for their neighbour, including their enemies. 
However, before we received such a precise teaching from the Council on the redemptive paschal mystery of Christ, we had to go through a number of issues in the editorial work on the official text. It may be worth noting some of them.

In relation to the redemption accomplished by the entire paschal mystery, it could be observed that in the pre-Council theology, the emphasis was placed on the death of Christ the Priest on the cross, on His bloody sacrifice, satisfaction in a substitute way: for the whole world, but above all for delusions ${ }^{25}$. In the works of the Council we also observe the development of thoughts concerning our problems. Of course, there were no problems in referring Christ's death to the mystery of Redemption. It should only be noted that the emphasis was placed on the fact that Christ died for all men ${ }^{26}$. All have therefore been redeemed, and none within mankind is deprived of participation in the fruits of Redemption.

It should also be noted that in the first editions of the text, the redemptive effectiveness of the resurrection was not properly emphasized, even though the bishops demanded it in their postulates expressed before the Council ${ }^{27}$. Even less has been said of this redemptive efficacy for the ascension and exile of the Holy Spirit. This resulted in a very strong intervention of the representatives of the Eastern Churches, especially I. Ziade emphasized the saving power of the resurrection that embraces man and the world ${ }^{28}$. Hence the fact of the resurrection in connection with the fact of the Incarnation. According to another theologian from Eastern Europe, P.P. Meouchi, it is suffering the consequences necessary to develop a so-called cosmic theology. For the word becoming flesh united the matter with itself and in a way, it was also connected with the deity. Therefore, the resurrection of Christ is the resurrection of mankind and mat$\operatorname{ter}^{29}$. In another of his speeches, I. Ziade also pointed to the lack of a certain spiritual vigour in the text because he did not sufficiently emphasise the central

25 Cf. Pontificium Atheneum Angelicum, facultas theologica, in: AD, p. I, vol. II, p. II, 14; C. P. Mutsaeits, in: AD, p. I, vol. II, p. II, 504-508; E. Clarizio, in: AD, p. I, vol. II, p. IV, 433; J. M. Koiando, in: AD, p. I, vol. II, p. III, 055; V. P. Kellenberg, in: AD, p. I, vol. II, p. VI, 421; R. Carboni, in: AD, p. I, vol. II, p. VII, 609; M. Fossati, in: AD, p. I, vol. II, p. III, 647. 675; J. Król, in: AD, p. I, vol. II, p. VI, 490-493; J. D’Avack, in: AD, p. I, vol. II, p. III, 143; D. Vignacour, in: AD, p. I, vol. II, p. I, 433.

26 Cf. Schema I, in: AS, vol. III, p. V, 121.

${ }^{27}$ Cf. A. Colette, in: AD, p. I, vol. II, p. VIII, 186-187; J. Neuhausler, in: AD, p. I, vol. II, p. I, 606; C. H. Helmsing, in: AD, p. I, vol. II, p. VI, 452; S. S. Congregatio S. Officii, in: AD, p. I, vol. III, 6.

28 Cf. I. Ziade, in: AS, vol. III, p. V, 535.

29 Cf. P.P. Meouchi, in: AS, vol. IV, p. II, 423. 
position of the risen Christ. Because you cannot understand the events taking place in today's world except in the light of the new creation that began in the resurrection. The mystery of the resurrection is not a second creation from nothing, but the liberation of life from the bondage of death. It is not only a continuation of a previous life or passing through death, it is a real novelty. This explains why we are already passing from the "old age" of the mortal world to the "newness" of the living world.

Nor was anything said at first about the Ascension. Neither in the first edition of the text nor in the statements of the Fathers about it could one notice any interest in the salvific value of this stage of the paschal mystery ${ }^{3031}$. Only recent editions of the text emphasised the link between the Ascension and the Resurrection and emphasized the role of Christ's rule over all creation ${ }^{32}$. It seems, however, that the Ascension is the phase of the whole Paschal Mystery of Christ, to which, unfortunately, only a minor significance in the mystery of redemption has been attributed.

(The teaching on the exile of the Holy Spirit was also developed, starting with a slight sign of it in the first Schema ${ }^{3334}$ and in a few statements of the Council Fathers after the first edition of the text. Schema II shows a certain enrichment of the pneumatological problem ${ }^{35}$. The last editions of the text point even more often to the role of the Holy Spirit in the saving work of Christ, thus responding to the interventions of the representatives of the Eastern Churches. One of them, P.P. Meouchi, even suggests that from such a point of view and interpretation it will be possible to unite the Eastern and Western traditions ${ }^{36}$. It is worth emphasising here, as in the case of the resurrection, the influence of Eastern theology on the teachings of the Second Vatican Council.

In demonstrating the value of the redemption of the violet, salvation from the bondage of Satan and sin is the focus. This would mean that the Council Fathers' thinking was "firmly rooted, anchored in the concept of redemption, understood" as, redemption from $\sin ^{37}$. The atonement and the new covenant

30 Cf. I. Ziade, in: AS, vol. IV, p. II, 438.

31 Cf. Episcopi Conferentdae Indonesiae, w: AS, vol. III, p. V, 689; P. M. Malachias von Diepem, in: AS, vol. II, p. VII, 371; A. Bea, w: AS, vol. III, p. V, 27.

32 Cf. Schema II, in: AS, vol. IV, p. I. 465; III Schema, in: AS, vol. IV, p. VI, 452.

33 Cf. Schema I, in: AS, vol. III, p. V, 124.130.140.141.

34 Cf. V. Costantini, in: AS, vol. III, p. VII, 218.

35 Cf. Schema II, in: AS, vol. IV, p. I, 449. 458. 465. 469.

36 Cf. P.P. Meouchi, in: AS, vol. IV, p. II, 423-424.

37 Cf. J. D’Avack, in: AD, p. I, vol. II, p. III, 150; H. Routhier, in: AS, vol. III, p. VII, 350; M. Maziers, in: AS, vol. III, p. V, 480; J. C. Rosenhammer, in: AS, vol. III, p. VII, 349; W. R. Power, 
with the Father has been marked out, and to a lesser degree. However, relatively much attention has been paid to the values of redemption, such as the service of life and the revelation of the mystery of love. We see a shift in emphasis in the understanding of the mystery of redemption from the negative aspect, that is, from redemption from sin and death, to the positive aspect, emphasising the value of life and love.

\section{Redemption and Creation}

As for the problem of the mutual relationship between creation and redemption, we can say that Schema I did not specify this relationship, as a result of the intervention of the Fathers ${ }^{3839}$. The second schema in number 50 expressed this reference in such a way that redemption contains within itself a creation. The original text reads: "Arctissime igitur historia hominum historia salutis iimplicatur, et in praesenti ac definitiva oeconomia ordo redemiptionis in se ordinem creationis includlt." In number 51, we still have confirmation of the "Imprimís, cum ordo redemiptionis oirdinem creationis comprehendat..." However, after the renewed interventions of the Council Fathers ${ }^{40}$, the next editions of the text, ${ }^{41}$ followed by the official text Gaudium et Spes, take a more cautious stance, choosing a compromise solution. The final text of Gaudium et Spes says nothing expresis verbis about the mutual relationship between redemption and creation. It speaks only of one and the same God the Creator and Redeemer, of the dignity of all created things (GS 41.10).

in: AS, vol. III, p. VII, 342; C. Rada Senosiaią in: AS, vol. III, p. VII, 62; V. M. Costantini, in: AS, vol. IV, p. VI, 464.

38 Cf. K. Wojtyła, in: AS, vol. III, p. V, 303; Directiones profutura elaboratione textus, in: AS, vol. III, p. V, 200; R. Gonzales Moralejo, in: AS, vol. III, p. V, 388; P. von Streng, in: AS, vol. III, p. V, 371.

39 Cf. Schema II, in: AS, vol. IV, p. I, 469.

40 Cf. Conferentia Episcoporum Linguae Germanieae et Scandiae, in: AS, vol. IV, p. II, 906; K. Wojtyła, in: AS, vol. IV, p. II, 661. F. Franie, in: AS, vol. IV, p. II, 734; J.B. Evangelisti, in: AS, vol. IV, p. II, 717; M. Wehr, in: AS, vol. IV, p. IÏ, 873; P.J. Schmitt, in: AS, vol. IV, p. III, 118; S. Hien Nguyen Van Hoa, in: AS, vol. IV, p. II, 800; H. Jenny, in: AS, vol. IV, p. II, 774; Pluires Patres Conciliares Galliae, in: AS, vol. IV, p. II, 917.

41 Cf. Scheme III, in: AS, vol. IV, p. VI, 465; Scheme IV, in: AS, vol. IV, p. VII, 265. 


\section{Summary}

Analysing the whole process of the development of the doctrine of redemption in Gaudium et Spes, we can conclude that the Council responded to the demands expressed before the beginning of the doctrine. It remained faithful to the teachings of St Thomas Aquinas, while preserving the essential content of his doctrine, although it expressed it in a new language. The Council was able to positively explain the doctrine of the mystery of redemption, without arguing with various contemporary theological tendencies. Redemption is shown as the work of Jesus Christ through His salvific Incarnation and the redemptive paschal mystery of death, resurrection, ascension and exile of the Holy Spirit. Redemption freed man from the bondage of Satan and sin, became a new covenant with the Father, reconciled delusions with God and with himself, merited life and revealed the mystery of love. Redemption is a great event in the history of salvation, which begins with the work of Creation. From the history of the various editions of Gaudium et Spes, from the interventions of the Council Fathers and from the solutions to the theological problems relating to the whole reality of the modern world, we can conclude that the Pastoral Constitution on the Church points to the relationship between creation and redemption, speaking of creation in the perspective of redemption and defining redemption as the renewal of creation in Christ. 